\title{
Effect of leaf and bark aqueous extract of Anogeissus latifolia on growth performance of Vigna unguiculata
}

\author{
Jahangeer A. Bhat, Munesh Kumar*, Bhupendra Singh \\ Department of Forestry and Natural Resources, Hemwati Nandan Bahuguna Garhwal University, Uttarakhand, India; \\ *Corresponding Author: muneshmzu@yahoo.com
}

Received 6 September 2011; revised 17 October 2011; accepted 27 October 2011.

\begin{abstract}
The present study was carried out to assess the effect of leaf and bark aqueous extract of Anogeissus latifolia tree on Vigna unguiculata traditional crop to understand the suitability of treecrop combination in agricultural fields. Different concentrations of leaf $(1 \%, 3 \%$ and $5 \%)$ and bark (1\%, $3 \%$ and $5 \%)$ aqueous extract of $A$. latifolia were used to study radicle and plumule growth of $V$. unguiculata. The leaf and bark aqueous extract have shown minimum allelopathic effect on V. unguiculata and suppressed/stimulated radicle and plumule growth under different concentrations. The wide distribution of $A$. latifolia in a sub-tropical region of Garhwal Himalaya, provides good fodder fuel wood and timber to the villagers. Therefore introducing Anogeissus latifolia in agricultural field and maintaining the existed trees at boundaries of agricultural fields can be useful to the villagers requirements and wherever the possible allopathic effect exit can be minimized by lopping the branches of trees and use of naturally flecked off bark for fuel wood purposes.
\end{abstract}

Keywords: Aqueous Extract; Bark; Leaf; Radicle and Plumule; Growth

\section{INTRODUCTION}

Allelopathy is a biological phenomenon by which an organism produces one or more chemicals that influence the growth, survival and reproduction of nearby species. These chemicals are known as allelochemicals and can have beneficial (positive allelopathy) or detrimental (negative allelopathy) effects on the target species.

Anogeissus latifolia Wall ex Bedd., belongs to the family combretaceae [1]. This is a tree of tropical and subtropical climatic regions; it grows throughout the sub- Himalayan tract up to an altitude of $1200 \mathrm{~m}$ above mean sea level (masl) in central India and a large part of the Indian Peninsula hills at an elevation of about 1200 $m[2,3]$. It grows with the association of moist Shiwalik Sal forests, dry Shiwalik Sal forests, southern dry mixed deciduous forests, dry peninsular Sal forests and northern dry mixed deciduous forests [4]. It is one of the most useful trees in India. Its leaves contain large amounts of tannin which is used in India. The trees are the source of Indian gum which is also known as ghatti gum, and is used for calico printing. The leaves are fed by Antheraea paphia moth which produces the tassar silk used for commercial importance. Chemically leaves, bark and heartwood yield quinic and shikmik acids; leaves contain gallotannin (90\% - 95\% of the tannins). The young leaves and shoots contain 50\% tannins (dry basis). The bark contains $12 \%$ - 18\% tannins. Heartwood contains gallic acid, ellagic acid, its derivatives, quercetinandmyricetin. The gum is mainly the calcium salt of a complex, high molecular weight polysaccharic acid (ghattic acid).

Vigna unguiculata (L) Walp (cowpea) is cultivated over more than nine million hectares in tropical area, in the Mediteranean basin and in the United States [5]. Worldwide, it is estimated that 37 million tones are annually produced [6]. Cowpea is a source of high quality protein which contained adequate levels of most essential amino acids for children and all essential amino acids for adults. The digestibility of cowpea is higher than the other common legumes [7].

In the sub-tropical region of Garhwal Himalaya, A. latifolia is growing in the forest areas and closed to agricultural fields, because most of the agriculture land is closed to forest area and people are using this tree for various daily needs as a multipurpose tree. The closeness of this tree in agriculture fields, shed their leaves especially in deciduous period and lead to deposi- tion of leaf litter and naturally flecked off bark in agri- culture land. Literature revealed that no studies have been reported so far on the effect of leaf and bark of A. latifolia on any agriculture crops in this sub-tropical region of Garhwal 
Himalaya. Therefore, the attempt was made with the objective to find out the effect of leaf and bark aqueous extract of A. latifolia on radicle and plumule growth of $V$. unguiculata

\section{MATERIALS AND METHODS}

The samples of mature leaves and naturally flecked off bark were collected from middle age growing trees from natural condition and brought to the experimental laboratory of Department of Forestry and Natural Resources, HNB Garhwal University, Srinagar Garhwal ( $30^{\circ} 13^{\prime} \mathrm{N}$ latitude and $78^{\circ} 48^{\prime} \mathrm{E}$ longitude) at an elevation of $550 \mathrm{~m}$ above sea level. The collected samples were Sun dried for 10 days/or required till complete moisture loss from the samples and ground to a fine powder separately in a mechanical grinder. The powder was passed through $1.5 \mathrm{~mm}$ mesh and weighed to $1 \mathrm{~g}, 3 \mathrm{~g}$ and $5 \mathrm{~g}$ (leaf and bark) and transferred to well labelled conical flask and $100 \mathrm{ml}$ of double distilled water was added to each flask. The dilution extracts were filtered through Whatman No. 1 filter paper to get aqueous extracts of $1 \%, 3 \%$, and $5 \%$ solutions and the flasks were left for 48 hours at room temperature $\left(25^{\circ} \mathrm{C} \pm 2{ }^{\circ} \mathrm{C}\right)$. The effects of aqueous extract (leaf and bark) on radicle and plumule growth of Vigna unguiculata was tested by placing 20 seeds in Petri dishes (15 cm diameter) with three replicates for each concentration. The seeds were germinated on filter paper soaked in the aqueous leaf and bark extract of different concentrations at $25^{\circ} \mathrm{C} \pm 2{ }^{\circ} \mathrm{C}$ in laboratory, while distilled water was used for control treatment. Moisture in the Petri dishes was maintained by adding aqueous extracts or distilled water as required.

\section{RESULTS AND DISCUSSION}

The results of present study showed that the highest radicle length $(9.61 \pm 0.98 \mathrm{~cm})$ of Vigna unguiculata in leaf aqueous extract was in 5\% concentration followed by $3 \%(8.11 \pm 1.25 \mathrm{~cm})$ and $1 \%(7.21 \pm 0.41 \mathrm{~cm})$. The radicle length increased with increasing concentration of leaf aqueous extract (Table 1), which was comparatively higher than the control $(5.71 \pm 0.65)$. Similarly the plumule growth of $V$. unguiculata in the leaf aqueous extract reduced with increasing concentration. The highest length of plumule was $8.55 \pm 1.43 \mathrm{~cm}(1 \%)$, followed by $7.77 \pm 3.67 \mathrm{~cm}(3 \%)$ and $7.16 \pm 0.73 \mathrm{~cm}(5 \%)$. The plumule growth compared to control was higher in $1 \%$ leaf aqueous extract and lower in 3\% and 5\% leaf aqueous extract.

In bark aqueous extract radicle growth reduced with increasing aqueous concentration as $6.05 \pm 0.94 \mathrm{~cm}$ (1\%), $5.59 \pm 0.39 \mathrm{~cm}$ (3\%) and $4.56 \pm 1.14 \mathrm{~cm}$ (5\%). However, the results of plumule length was reverse than the radicle length in bark aqueous extract, which increased with increasing aqueous concentration as $7.19 \pm$ $0.54,7.51 \pm 1.56$ and $9.18 \pm 0.40 \mathrm{~cm}$ for $1 \%$, $3 \%$ and $5 \%$ respectively (Table $\mathbf{1}$ ).

The reduction percentages of radicle and plumule lengths were estimated in the leaf and bark aqueous extract compared with control. The radicle length in all the concentrations of leaf and 1\% concentrations of bark was stimulated however $3 \%$ and $5 \%$ of aqueous extract of bark suppressed its growth (Figure 1). Similarly 5\% concentration of bark and $1 \%$ concentration of leaf stimulated plumule growth and other concentrations of leaf and bark suppressed it (Figure 1).

Most published work has revealed that foliage leachates are a potent source of toxic metabolites and their toxic effects are species specific [8-10]. But our study reveals that leaf aqueous extract stimulate the growth of radicle compared to control, with increase in the percentage of aqueous extract concentration, the radicle growth increased however the bark extract showed decrease in growth of plumule with increased in the aqueous extract concentration of solution. The plumule

Table 1. Radicle and plumule growth of $V$. unguiculata in aqueous extract of $A$. latifolia.

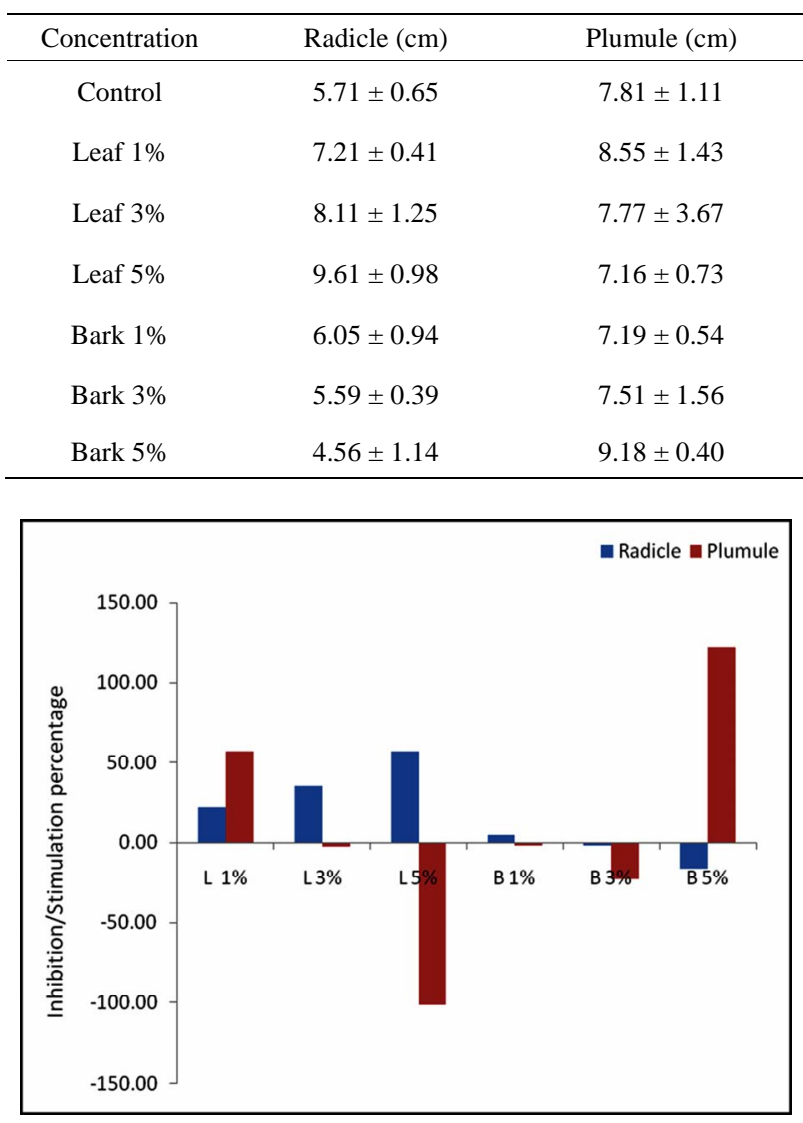

Figure 1. Reduction/stimulation percentage of radicle and plumule growth over control (L-Leaf and B-bark). 
growth increased by the bark extracts as the increase in concentration of solution the growth of plumule increased. Overall the effect of bark and leaf aqueous extract showed minimum inhibitory effect to the growth of radicle and plumule of Vigna unguiculata.

\section{CONCLUSIONS}

The study concludes that both leaf and bark extract have minimum allelopathic effect on Vigna unguiculata which suppressed/stimulate both radicle and plumule growth. Although, keeping in view the multipurpose value of Anogeissus latifolia tree for the requirement of villagers, the tree should be preferred in agricultural fields. The branches of the tree can be used as fodder and the bark for fuel wood to reduce the alleopathic effect to V. unguiculata and other agricultural crops.

\section{REFERENCES}

[1] Luna, R.K. (2005) Plantation trees. International Book Distributor, Dehradun.

[2] Rodger, A. (1913) Note on dhaura of bakli (Anogeissus latifolia wall.). Bulletin, Calcutta Superintendent Government Printing, Calcutta, 21, 15.

[3] Troup, R.S. (1921) The silviculture of Indian trees. Clarendon Press, Oxford, 1-3.
[4] Champion, H.G. and Seth, S.K. (1968) A revised survey of the forest types of India. Manager of Publications, Delhi, 1968.

[5] Guigaz, M. (2002) Memento de l'agronume. Eds de CIRAD-CRET Ministère des affaires étrangères, Paris, 69-872.

[6] Langyintuo, A.S., Lowenbrg-Deboer, J., Faye, M., Lambert, D., Ibro, G., Moussa, B., Kergna, A., Kushwaha, S., Musa, S. and Ntoukam, G. (2003) Cowpea supply and demand in West and Central Africa. Field Crops Research, 82, 215-231. doi:10.1016/S0378-4290(03)00039-X

[7] Alessandra, R., Karina, S., Patricia, S., Marcelo, S.N., Gilberto, B.D., Sergio, T.F. and Cristiana, P. (2004) Biological evaluation of a protein isolate from cowpea (Vigna unguiculata) seeds. Food Chemistry, 87, 491-499. doi:10.1016/j.foodchem.2003.12.023

[8] May, F.E. \& Ash, J.E. (1990) An assessment of the allelopathic potential of Eucalyptus. Australia Journal Botany, 38, 245-254.

[9] Bhatt, B.P., Chauhan, D.S. \& Todaria, N.P. (1993) Phytotoxic effects of tree crops on germination and radicle extension of some food crops. Tropical Science, 33, 69-73.

[10] Todaria, N.P., Singh, B. \& Dhanai, C.S. (2005) Allelopathic effects of tree leachate on germination and seedling growth of field crops. Allelopathy Journal, 15, 285294. 